\title{
Mosaicism with Translocation: Autoradiographic and Fluorescent Studies of an Inherited Reciprocal Translocation $\mathrm{t}(2 \mathrm{q}+; 14 \mathrm{q}-)$
}

\author{
JACOB A. REISS, HERMAN E. WYANDT, R. ELLEN MAGENIS, \\ EVERETT W. LOVRIEN, and FREDERICK HECHT

\begin{abstract}
From the Division of Medical Genetics, Department of Pediatrics and Genetics Clinic, Crippled Children's Division, University of Oregon Medical School, Portland, Oregon 97201, USA
\end{abstract}

Translocation mosaicism is an extremely rare occurrence. We have briefly reported the finding in different families of 2 patients with translocation mosaicism (Magenis et al, 1970). One patient is reported here.

\section{Case Report}

The propositus was born on 12 July 1970 after a fullterm gestation. The father was 26 . The mother was 21 years old; she had previously had 3 consecutive firsttrimester spontaneous abortions. The amniotic fluid and the baby were both meconium stained. The umbilical cord was tightly coiled around his neck, and he required vigorous resuscitation. The Apgar score was 4 at 1 minute. At birth his weight was $2.4 \mathrm{~kg}$, length $46 \mathrm{~cm}$, head circumference $33 \mathrm{~cm}$, chest circumference $33.5 \mathrm{~cm}$. Dolichocephalic head, small palpebral fissures, right exotropia, retrocessed ears, increased nasolabial distance, upturned nares, cleft soft palate, large mouth, and micrognathia were noted (Fig. 1). Redundant skin was present over the lateral and posterior aspect of the neck. Flexion contractures of the proximal interphalangeal joints of the 3rd and 4th fingers were present bilaterally. The dermal ridges were hypoplastic. The dermatoglyphic patterns differed from his parents. He had 6 arches while his mother had one tented arch and his father had no arches. The fingernails were small. The pelvis was small and the hips were tight to abduction. No testis was palpable on the left and on the right it was felt in the inguinal canal. A left inguinal hernia was present. The infant had a weak, hoarse cry and had generalized hypertonia and hyperreflexia.

During the first month of life intermittent episodes of tachypnoea, tachycardia, and cyanosis occurred. A grade III/VI harsh pansystolic murmur was heard. Heart failure was present and digitalis was administered until he was 4 months. At that time an electrocardiogram

Received 27 October 1971. showed right ventricular hypertrophy and radiology showed a small heart. Tetralogy of Fallot was diagnosed. Early in the neonatal period there was also intermittent distention of the abdomen due to rectal stenosis. This was successfully treated by rectal dilatation.

Growth and development have been consistently retarded. At age 10 months his weight was $3.8 \mathrm{~kg}$, length $56.5 \mathrm{~cm}$, head circumference $40.3 \mathrm{~cm}$; all these values are below the 3rd centile. He could not sit without support. There was head lag when he was pulled to a sitting position. Only occasionally would he bear weight of his legs. He had no verbalization, failed to reach fos objects, followed sporadically with his eyes, and smiled rarely. His estimated development age was 2 months.

Chest radiographs revealed hypoplastic 12th ribs. Nuclear projections were demonstrated in increased numbers in his neutrophils. Starch gel haemoglobin electrophoresis was normal with $0.8 \%$ fetal haemoglobin at 10 months of age.

\section{Family Data}

A partial pedigree of the family is shown in Fig. 2. The father of the propositus had 3 normal sisters, one of whom had a son (IV.8) with Hirschsprung's disease (congenital aganglionic megacolon). The child developed normally and had no other congenital abnormalities, but died at 9 months from bronchopneumonia and toxic enterocolitis. A deceased paternal great uncle (II.2) had been mentally retarded, but reportedly had no malformations. Both of the paternal grandparents were Portuguese; the paternal great grandparents (I.1 and I.2) were born in the Azores. Consanguinity between the parents was denied.

\section{Chromosome Studies}

Chromosome Studies of the Propositus. Two cell lines were observed in cultured lymphocytes (Table I). One contained a translocation 


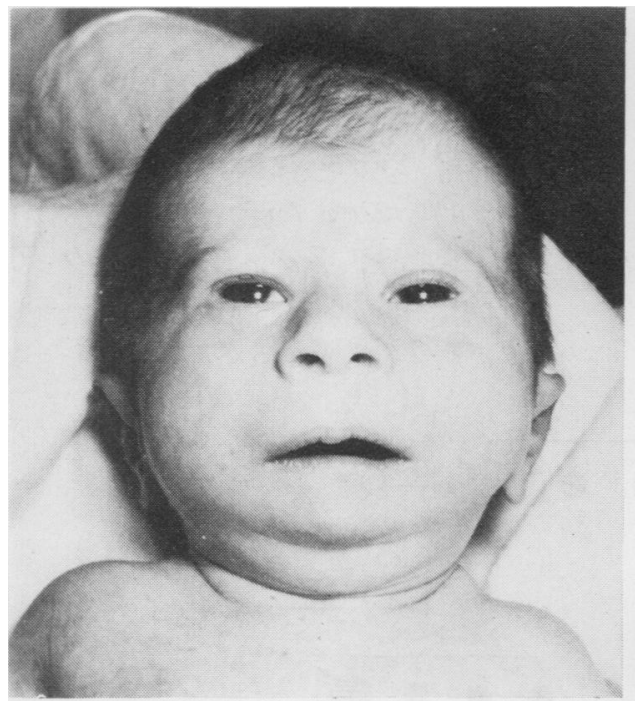

$1 \mathrm{a}$

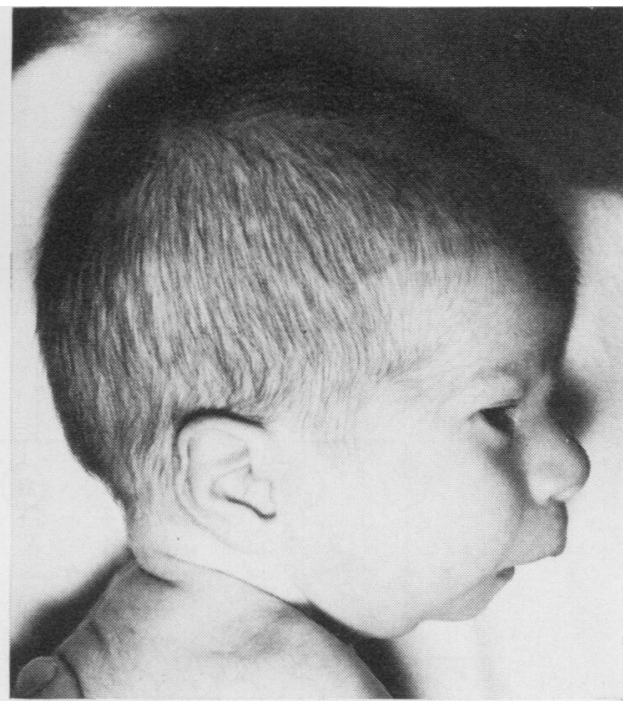

$1 \mathrm{~b}$

Fig. 1. The propositus at age 2 weeks. (a) The small palpebral fissures, right exotropia, large mouth, and increased nasolabial distance are shown. (b) Dolichocephaly, retrocessed ears, upturned nares, and micrognathia are seen here.

involving a chromosome No. 2 and a $\mathrm{D}$ chromosome (Fig. 3a) interpreted as $46, \mathrm{XY}, \mathrm{t}(2 \mathrm{q}+; \mathrm{Dq}-)$. The second cell line was identical except for an additional Dq - chromosome (Fig. 3b).

Skin fibroblast cultures harvested after 44 days in culture also contained both cell lines. Equal numbers of the 2 cell types were observed in the lymphocyte cultures, while the skin fibroblast cultures showed clear predominance of the aneuploid cell line (Table I).

Chromosome Studies of other Family Members. Chromosome analyses were performed on the other family members as indicated in the pedigree (Fig. 2). The detailed results are shown in Table I. The translocation involving a chromosome 2 and a D chromosome was also discovered in the father (III.7) and paternal grandfather (II.3). All other family members studied had normal karyotypes.

Autoradiography. Lymphocytes and fibroblasts cultured from the propositus were studied by autoradiography after continuous late-labelling with tritiated thymidine for 6 hours before harvest, as described by Schmid (1963). The late-labelling

TABLE I

CHROMOSOME STUDIES

\begin{tabular}{|c|c|c|c|c|c|}
\hline & & \multirow{2}{*}{ Tissue* } & \multicolumn{2}{|c|}{ Number of Metaphases } & \multirow[b]{2}{*}{ Interpretation } \\
\hline & & & $\begin{array}{c}\text { With } 46 \\
\text { Chromosomes } \\
\end{array}$ & $\begin{array}{c}\text { With } 47 \\
\text { Chromosomes } \\
\end{array}$ & \\
\hline IV.12 & Propositus & $\mathbf{L}$ & $\begin{array}{r}43 \\
2 \\
\end{array}$ & $\begin{array}{l}56 \\
32\end{array}$ & $\begin{array}{l}46, X Y, t(2 q+; 14 q-) / 47, X Y, t(2 q+; 14 q-),(14 q-)+ \\
46, X Y, t(2 q+; 14 q-) / 47, X Y, t(2 q+; 14 q-),(14 q-)+\end{array}$ \\
\hline III.7 & Father & $\mathrm{L}$ & $\begin{array}{l}77 \\
24 \\
\end{array}$ & & $\begin{array}{l}46, X Y, t(2 q+; 14 q-) \\
46, X Y, t(2 q+; 14 q-) \\
\end{array}$ \\
\hline III.8 & Mother & $\mathbf{L}$ & 56 & & $46, \mathrm{XX}$ \\
\hline II.3 & Paternal grandfather & $\mathbf{L}$ & 36 & & $46, X Y, t(2 q+; 14 q-)$ \\
\hline II.2 & Paternal grandmother & $\mathbf{L}$ & 32 & & $46, \mathrm{XX}$ \\
\hline III.4 & Paternal aunt & $\mathbf{L}$ & 22 & & $46, \mathrm{XX}$ \\
\hline III.5 & Paternal aunt & $\mathbf{L}$ & 39 & & $46, \mathrm{XX}$ \\
\hline
\end{tabular}

* $\mathrm{L}=$ lymphocytes; $\mathrm{F}=$ skin fibroblasts. 


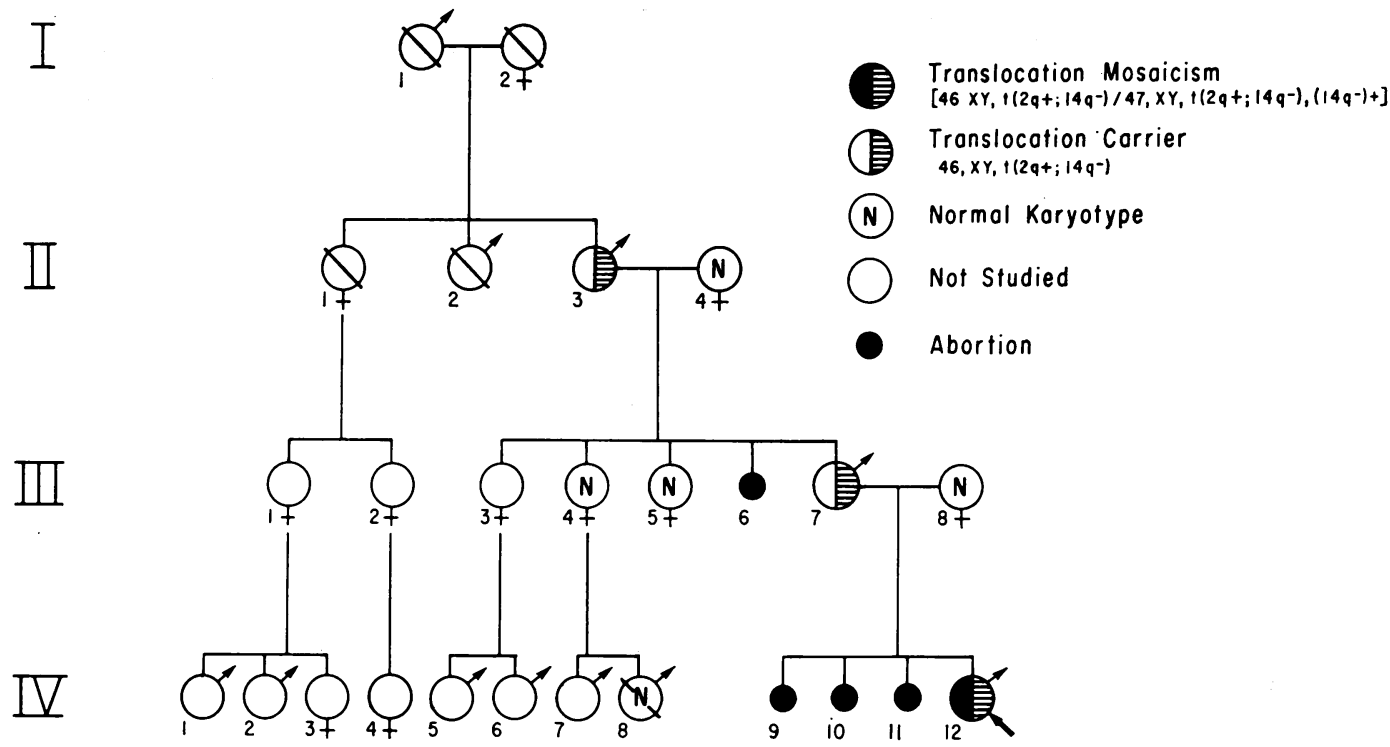

FIG. 2. The pedigree of family 1282 .

patterns of the D group chromosomes in both the 46 and 47 cell lines are illustrated in Fig. 4.

Thirty-seven metaphases were scored for the missing $\mathrm{D}$ chromosome. Twenty-one of the 37 cells had autoradiographic patterns consistent with a missing chromosome No. 14, 13 of the 37 had ambiguous labelling patterns, and 3 had patterns consistent with a missing 13 or 15 .

The autoradiographic patterns of the $\mathrm{Dq}-$ chromosomes themselves were analysed; 34 of 61 labelled similarly to chromosome $14 ; 12$ labelled with ambiguous patterns but were possibly 14; 15 labelled with patterns other than chromosome 14 . Thus, $74 \%$ (46 of 61 ) of the Dq - chromosomes had a pattern consistent with that of chromosome 14 .

The autoradiographic patterns of the two $\mathrm{Dq}-$ chromosomes in the aneuploid line of cells were also compared. Twenty-four cells were scored. Of these, $15(63 \%)$ showed both $\mathrm{Dq}$ - chromosomes with patterns definitely or possibly consistent with No. $14 ; 2$ (9\%) showed both Dq - chromosomes with patterns definitely or possibly consistent with No. 15; and the remaining $7(29 \%)$ showed dis-ce cordant labelling patterns.

Fluoromicroscopy. Metaphases from the patient, his father, and his paternal grandfather were stained with quinacrine mustard (Caspersson, Zech, and Johansson, 1970a) and photographed with a Zeiss Photomicroscope II equipped with a Planachromat oil immersion lens, HB200 mercury light source, BG12 excitation filter, and $530 \mathrm{~nm}$ barrier filter. The resultant $35 \mathrm{~mm}$ negatives were printed on Kodabromide F-5 and for greater contrast on Brovira Agfa grade 6 photographic paper. The same metaphases were then restained with Giemsa

TABLE II

GENETICS MARKER STUDIES

\begin{tabular}{|c|c|c|c|c|c|c|c|c|c|c|c|c|c|c|c|c|}
\hline & & \multirow{2}{*}{$\begin{array}{l}\text { Date of } \\
\text { Birth }\end{array}$} & \multirow{2}{*}{ MNS } & \multirow{2}{*}{$\mathbf{P}$} & \multirow{2}{*}{ Rhesus } & \multicolumn{2}{|c|}{ Lewis (Le) } & \multicolumn{2}{|c|}{ Duffy (Fy) } & \multicolumn{2}{|c|}{ Kidd (Jk) } & \multirow{2}{*}{$\begin{array}{c}\text { Acid } \\
\text { Phos- } \\
\text { phatase }\end{array}$} & \multirow{2}{*}{ PGM } & \multirow{2}{*}{ LP } & \multirow{2}{*}{$\begin{array}{l}\text { Secre- } \\
\text { tor }\end{array}$} & \multirow{2}{*}{$\underset{\text { lase }}{\text { Amy- }}$} \\
\hline & & & & & & $\mathbf{a}$ & $\mathrm{b}$ & $\mathbf{a}$ & $b$ & $\mathbf{a}$ & $\mathbf{b}$ & & & & & \\
\hline $\begin{array}{l}\text { II. } 3 \\
\text { II.4 } \\
\text { III.4 } \\
\text { III. } 5 \\
\text { III. } 7 \\
\text { III. } 8 \\
\text { IV.12 }\end{array}$ & $\begin{array}{l}\text { Grandfather } \\
\text { Grandmother } \\
\text { Aunt } \\
\text { Aunt } \\
\text { Father* } \\
\text { Mother } \\
\text { Propositus* }\end{array}$ & $\begin{array}{l}1.3 . ' 14 \\
4.13 . ' 18 \\
5.31 . ' 48 \\
9.7 .^{\prime} 48 \\
3.4 .^{\prime} 44 \\
9.8 .^{\prime} 48 \\
\text { 7.12.'70 }\end{array}$ & 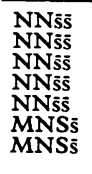 & $\begin{array}{l}+ \\
\dot{+} \\
\overline{+} \\
+ \\
+\end{array}$ & $\begin{array}{l}\text { DCcee } \\
\text { DCcee } \\
\text { DCCee } \\
\text { DCcee } \\
\text { dccee } \\
\text { DCCee } \\
\text { DCcee }\end{array}$ & $\begin{array}{l}\bar{z} \\
\overline{+} \\
\bar{y} \\
\overline{+}\end{array}$ & $\begin{array}{l}- \\
\overline{-} \\
\overline{-} \\
\overline{-}\end{array}$ & $\begin{array}{l}- \\
+ \\
+ \\
+ \\
+ \\
-\end{array}$ & $\begin{array}{l}+ \\
+ \\
+ \\
+ \\
+ \\
+ \\
+\end{array}$ & $\begin{array}{l}+ \\
+ \\
+ \\
+ \\
+ \\
+ \\
+\end{array}$ & $\begin{array}{l}\overline{+} \\
+ \\
+ \\
+ \\
+ \\
+\end{array}$ & $\begin{array}{l}\mathbf{B} \\
\mathbf{B} \\
\mathbf{B} \\
\mathbf{B} \\
\mathbf{B} \\
\mathbf{B A} \\
\mathbf{B A}\end{array}$ & $\begin{array}{l}2-2 \\
2-1 \\
2-1 \\
2-2 \\
2-1 \\
1-1 \\
1-1\end{array}$ & $\begin{array}{l}\overline{+} \\
\overline{-} \\
\overline{-} \\
-\end{array}$ & $\begin{array}{l}\text { Se } \\
\text { Se } \\
\text { Se } \\
\overline{\text { sè }} \\
\text { Se } \\
\text { Se } \\
\text { Se }\end{array}$ & $\begin{array}{l}\mathbf{A} / \mathbf{A} \\
\mathbf{A} / \mathbf{A} \\
\mathbf{A} / \mathbf{A} \\
\mathbf{A} / \mathbf{A} \\
\mathbf{A} / \mathbf{A} \\
\mathbf{A} / \mathbf{A B}\end{array}$ \\
\hline
\end{tabular}

* Family members with the translocation.

All family members had the following in common: $A^{1} ; \mathbf{L u}(\mathrm{a}-) ; \mathrm{K}(\mathrm{K}-, \mathrm{k}+) ; \mathrm{Di}^{\mathrm{a}}(-) ; \mathrm{Tf}(\mathrm{C}) ; \mathrm{Hp}(2-2) ; \mathrm{E}_{2}(\mathrm{~A}) ; \mathrm{E}_{1}(\mathrm{U}) ; \mathrm{AK}(1-1) ; 6 \mathrm{PGD}(\mathrm{A}) ;$
$\mathrm{an}(+) ; \mathrm{Xg}^{\mathrm{a}}(+) ; \mathrm{PTC}(+) ; \mathrm{Gc}(2-1) ; \mathrm{Gm}(1-, 2-12+)$. 


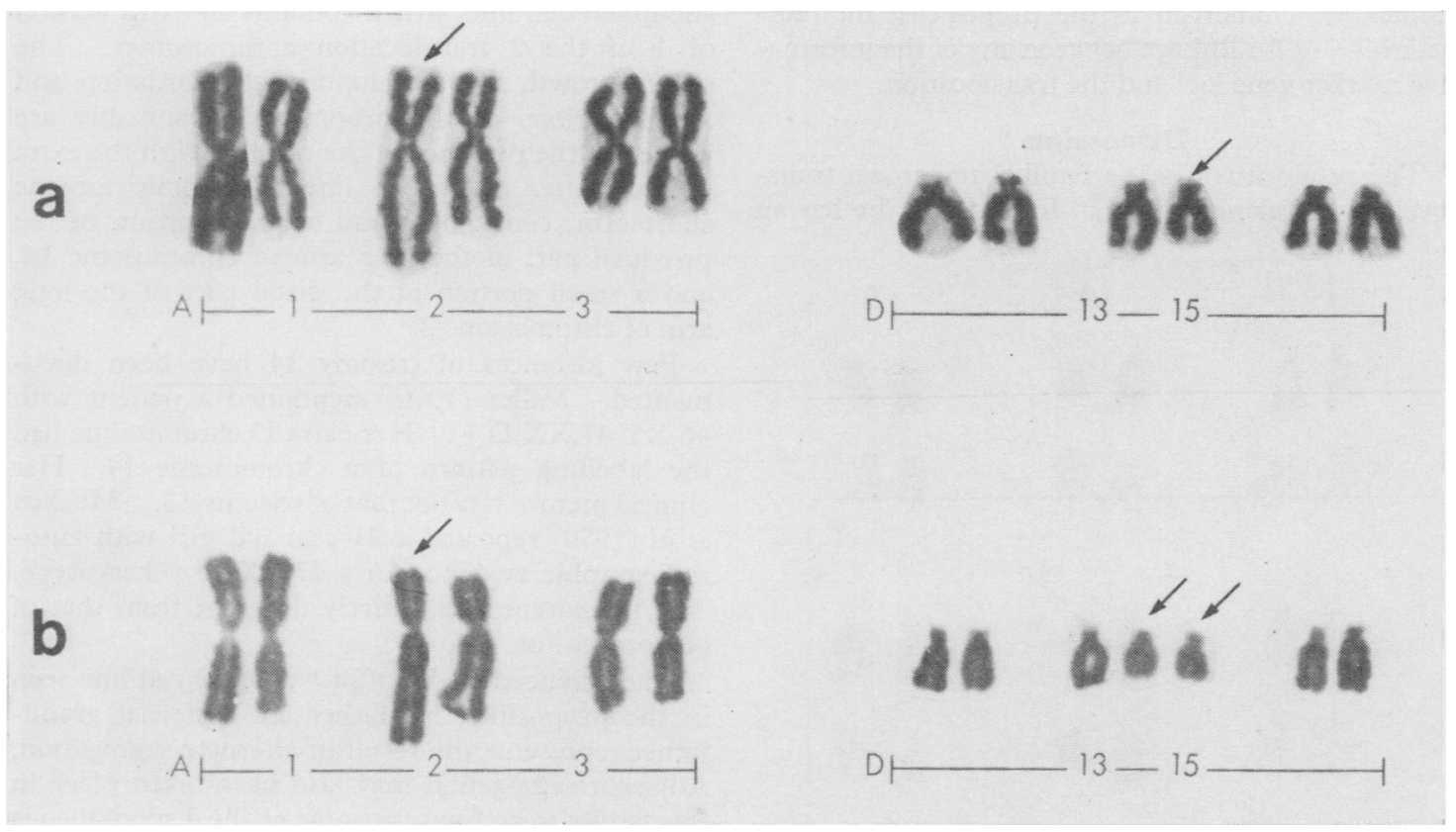

FIG. 3. Partial karyotypes of the two cell lines. (a) 46 count cell line, $46, X Y, t(2 q+; D q-)$ and (b) 47 count cell line, $47, X Y$, $t(2 q+;$ $\mathrm{Dq}-),(\mathrm{Dq}-)+$. The arrows indicate the chromosomes involved in the translocation. The translocation (in a) was found in the father and paternal grandfather of the propositus.

and rephotographed by conventional light microscopy.

A representative metaphase spread and partial karyotypes of 4 cells prepared with quinacrine mustard are shown in Fig. 5. Pairs of morphologically normal chromosomes were seen with the fluorescent patterns associated with chromosomes 13 and 15 (Caspersson et al, 1970b). However, only one morphologically normal chromosome 14 was observed, and the $\mathrm{Dq}$ - chromosome(s) had a pattern consistent with the proximal portion of chromosome 14.

Normally, chromosome No. 2 shows decreasing fluorescence over the distal (telomeric) part of the long arm, and chromosome No. 14 normally a region of relative negative-fluorescence just proximal to the more brightly fluorescent telomeric region. The morphologically normal chromosome No. 2 and chromosome No. 14 from the patient, his father, and paternal grandfather showed these patterns.

The region of gradually diminishing fluorescence was missing from the telomeric portion of the $2 q+$ chromosome. Conversely, the region of relative negative-fluorescence located just proximal to the more brightly fluorescent telomeric region associated with chromosome No. 14 was missing from the $14 q$ - chromosome, but was observed on the distal portion of the long arm of $2 q+$. We interpret these findings as consistent with a reciprocal translocation between 2q and 14q. Specifically, we believe that the findings speak against a one-way insertional translocation of material from No. 14 into the long arm of No. 2.

\section{Genetic Marker Studies}

Red cell antigens, red cell enzymes, plasma proteins, and saliva factors were investigated for genetic polymorphisms by standard techniques. The results are listed in Table II.

The propositus is $\operatorname{Le}(a+, b-)$ and a secretor. Normally Le $(a+)$ individuals are non-secretors. This discrepancy is probably due to his age; if so he will be $\operatorname{Le}(a-, b+)$ when he is older. His paternal aunt (III.5) is Le $(a+, b-)$ and a non-secretor. All others listed in Table II are secretors and probably $\mathrm{Le}(\mathrm{a}-, \mathrm{b}+)$ but since they are $\mathrm{A}_{1}$ at the $\mathrm{ABO}$ locus, $\mathrm{Le}^{\mathrm{b}}$ cannot be detected with our antiserum.

The Duffy blood group system is interesting in this family. III.4 is apparently Fy ${ }^{a} \mathrm{Fy}^{\mathrm{x}}$. She received the $\mathrm{Fy}^{\mathrm{x}}$ from her father (II.3) who is presumed to be $\mathrm{Fy}^{\mathrm{x}} \mathrm{Fy}^{\mathrm{b}}$ (Chown, Lewis, and Kaita, 1965). Further studies are being conducted to confirm this finding.

There was no evidence from the genetic marker 
studies for chimerism in the propositus, for nonpaternity, or for linkage between any of the informative marker gene loci and the translocation.

\section{Discussion}

The propositus has the familial reciprocal translocation in balanced form. In addition, he has an

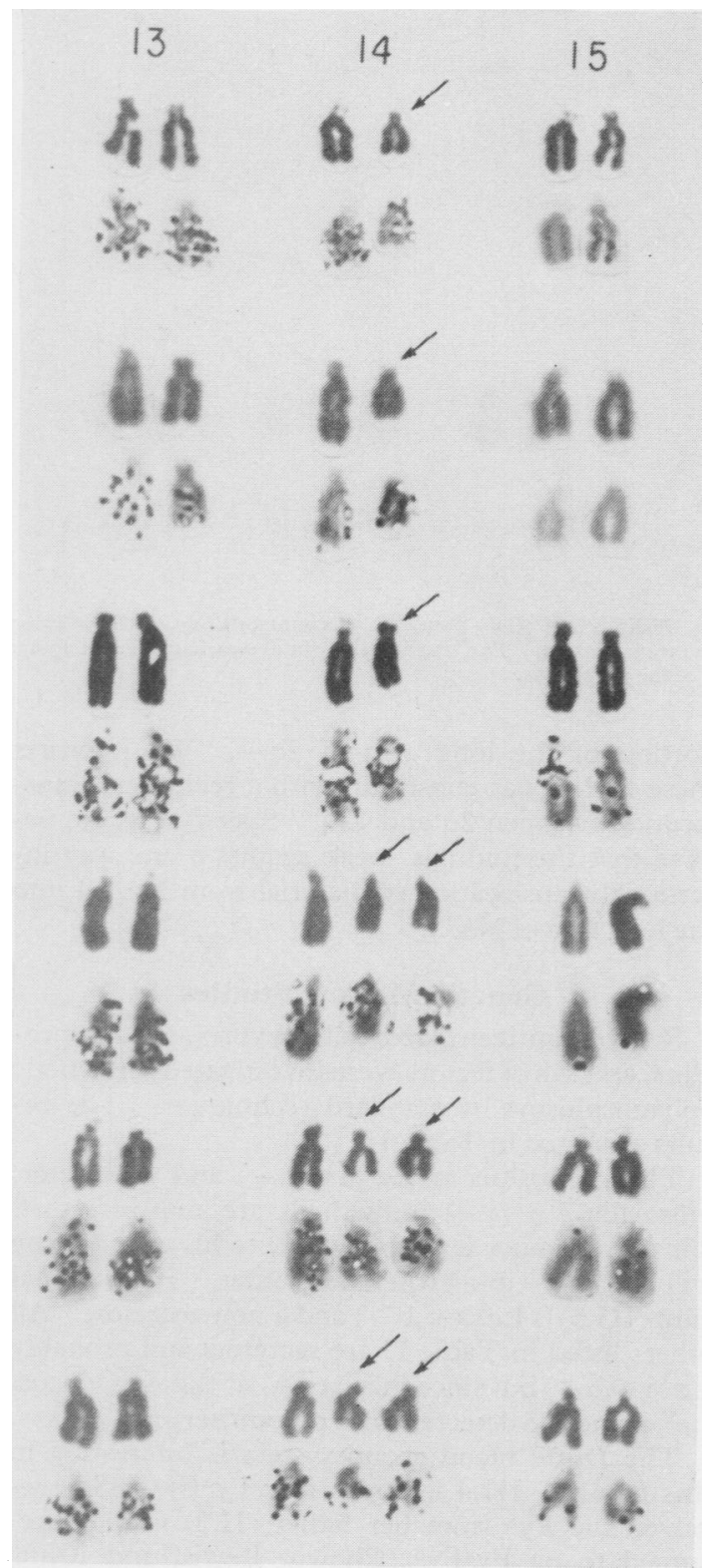

FIG. 4. Autoradiographic late-labelling patterns of the $D$ group chromosomes from 6 cells. The upper 3 cells had 46,XY,t $(2 q+$; $14 q-)$. The lower 3 cells had $47, X Y, t(2 q+; 14 q-),(14 q-)+$. The arrows indicate the $\mathrm{Dq}$ - chromosomes. aneuploid cell line, which contains an extra version of 1 of the 2 translocation chromosomes. The severe growth and developmental retardation and malformations in the propositus presumably are related to the presence of the cell line with the extra chromosome. This cell line is trisomic for the short arm, centromere and a large portion of the proximal part of the long arm of chromosome 14, and a small portion of the distal part of the long arm of chromosome 2 .

Few instances of trisomy 14 have been documented. Miller (1970) mentioned a patient with $46, \mathrm{XY} / 47, \mathrm{XX}, \mathrm{D}+$. Her extra D chromosome had the labelling pattern of a chromosome 14. Her clinical picture was not that of trisomy 13. Murken et al (1970) reported a $2 \frac{1}{2}$-year-old girl with autoradiographic evidence for a $47, \mathrm{XX}, 14+$ karyotype. The phenotype was entirely different from that of our propositus.

The balanced $46, X Y, t(2 q+; 14 q-)$ cell line seen in the propositus, his father and paternal grandfather represents the result of alternate segregation. Adjacent segregation may also have taken place in this family to account for some of the 4 spontaneous abortions which have occurred among the 9 pregnancies conceived by the translocation-carrying grandfather and father.

The origin of the mosaicism observed in the propositus is unknown. The presence of 2 morphologically similar appearing $14 \mathrm{q}-$ chromosomes. indicates that non-disjunction did not occur in meiosis I. There is no support from the genetic marker studies for double fertilization or for fusion of 2 zygotes to form a single embryo. The mosaicism in the propositus may be the result of (1) non-disjunction in meiosis II to create a $47, \mathrm{XY}, \mathrm{t}(2 \mathrm{q}+; 14 \mathrm{q}-),(14 \mathrm{q}-)+$ zygote with subsequent loss of a chromosome in an early postzygotic division; or (2) postzygotic non-disjunction in a balanced $46, X Y, t(2 q+; 14 q-)$ zygote.

It has been suggested (Weiss and Wolf, 1968) that balanced translocations may lead to an increased incidence of non-disjunction. This proposition, however, has not been tested adequately by determining the frequency of mosaicism in a properly ascertained series of persons with reciprocal translocations.

The presence of the rare Duffy blood group $\mathrm{Fy}^{\mathrm{x}}$ is of interest. When data from other family members are available, this system may prove useful in gene localization. Evidence for localization of the Duffy blood group and the uncoiler region of chromosome No. 1 has been demonstrated (Donahue et al, 1968). The Duffy blood group locus is also closely linked to the locus (Cae) which determines a form of 


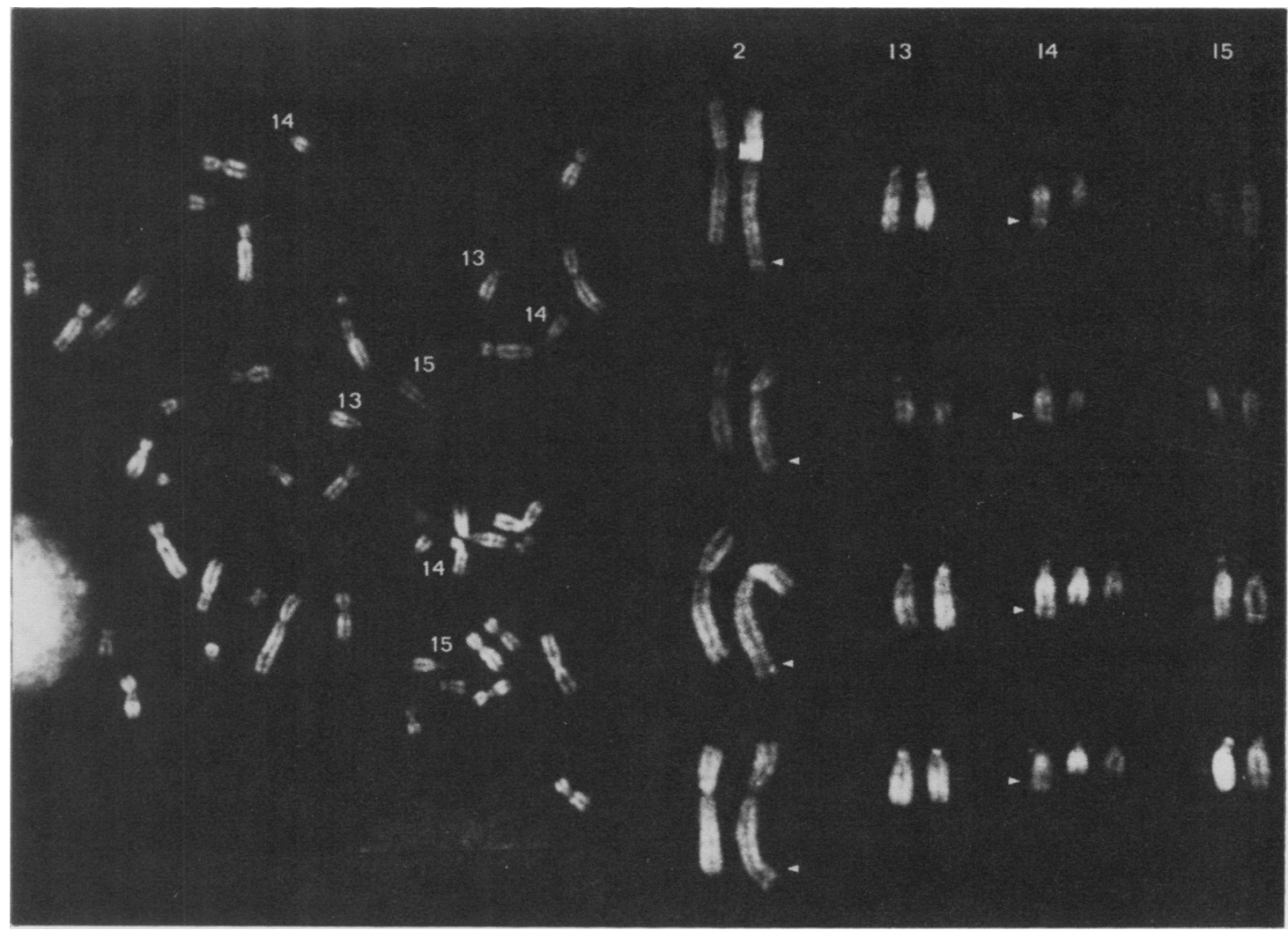

Fig. 5. (left) Fluorescent metaphase spread, $47, \mathrm{XY}, \mathrm{t}(2 \mathrm{q}+; 14 q-),(14 q-)+$, from the propositus. (right) Fluorescent staining of the $\mathrm{D}$ group and the chromosome 2 pairs from 4 cells. Both cell lines are represented. The arrows indicate the comparable banding patterns of the portions of chromosomes involved in the translocation, $t(2 q+; 14 q-)$.

congenital cataracts (Renwick and Lawler, 1963). Kamarýt, Adámek, and Vrba (1971) have suggested that human serum amylase $\left(\mathrm{Amy}_{2}\right)$ and the uncoiler region of chromosome 1 are tightly linked, and very recent work has demonstrated probable linkage of human serum amylase with the Duffy blood group (Hill, Rowe, and Lovrien, 1972). Close linkage, therefore, presumably exists for the loci Fy, Cae, and $\mathrm{Amy}_{2}$ and these loci are probably in close proximity to the uncoiler region of chromosome 1.

\section{Summary}

A rare translocation, $t(2 q+; D q-)$, is reported. The translocation was ascertained through an infant with multiple malformations and psychomotor retardation in whom 2 cell lines were discovered. Both lines contained the translocation, one cell line being balanced with $46, X Y, t(2 q+$; $14 \mathrm{q}-)$, whereas the other line was aneuploid with $47, \mathrm{XY}, \mathrm{t}(2 \mathrm{q}+, 14 \mathrm{q}-),(14 \mathrm{q}-)+$.
The $\mathrm{D}$ chromosome involved was determined to be No. 14 by autoradiography and by quinacrine fluoromicroscopy. Quinacrinefluoromicroscopy confirmed loss of material from a No. 14 chromosome and added material on $2 \mathrm{q}$ indicating a reciprocal translocation between the distal portions of $2 q$ and $14 \mathrm{q}$.

Six, of 26 genetic loci investigated in the family, were informative; there was no evidence for linkage with the breakpoints of $2 \mathrm{q}$ or $14 \mathrm{q}$.

J.A.R. and R.E.M. were postdoctoral research fellows on a National Institute of Health genetics training grant NICHD 00165 . The work was supported by NIH grants AMCA 13173 and HD 05082 and by a grant from the Children's Bureau for a genetics programme.

\section{REFERENCES}

Caspersson, T., Zech, L., and Johansson, C. (1970a). Analysis of human metaphase chromosome set by aid of DNA-binding fluorescent agents. Experimental Cell Research, 62, 490-492.

Caspersson, T., Zech, L., Johansson, C., and Modest, E. J. (1970b). Identification of human chromosomes by DNA-binding fluorescent agents. Chromosoma, 30, 215-227. 
Chown, B., Lewis, M., and Kaita, H. (1965). The Duffy blood group system in Caucasians: Evidence for a new allele. American Fournal of Human Genetics, 17, 384-389.

Donahue, R. P., Bias, W. B., Renwick, J. H., and McKusick, V. A. (1968). Probable assignment of the Duffy blood group locus to chromosome 1 in man. Proceedings of the National Academy of Sciences, 61, 949-955.

Hill, C., Rowe, S., and Lovrien, E. (1972). Probable linkage between human serum amylase $\left(\mathrm{Amy}_{2}\right)$ and Duffy blood group. Nature, 235, 162-163.

Kamarýt, J., Adámek, R., and Vrba, M. (1971). Possible linkage between uncoiler chromosome UN 1 and amylase polymorphism Amy $_{2}$ loci. Humangenetik, 11, 213-220.

Magenis, R. E., Wyandt, H., Reiss, J., and Hecht, F. (1970). Mosaicism occurring with ring, translocation, and deletion chro- mosomes. (Abstr.) American fournal of Human Genetics, 22, 10a$11 \mathrm{a}$.

Miller, O. J. (1970). Autoradiography in human cytogenetics. In Advances in Human Genetics, Vol. 1, Chap. 2, p. 70, ed. by $\mathrm{H}$. Harris and K. Hirschhorn. Plenum Press, New York.

Murken, J. D., Bauchinger, M., Palitzsch, D., Pfeifer, H., Suschke, J., and Haendle, H. (1970). Trisomie $\mathrm{D}_{2}$ bei einem $2 \frac{1}{2}$ jährigen Mädchen (47,XX,14+). Humangenetik, 10, 254-268.

Renwick, J. H. and Lawler, S. D. (1963). Probable linkage between a congenital cataract locus and the Duffy blood group locus. Annals of Human Genetics, 27, 67-84.

Schmid, W. (1963). DNA replication patterns of human chromosomes. Cytogenetics, 2, 175-193.

Weiss, L. and Wolf, C. B. (1968). Familial C/G translocation causing mitotic nondisjunction. American fournal of Diseases of Children, 116, 609-614.

Syndrome of Pigmentary Retinal Degeneration, Cataract, Microcephaly, and Severe Mental Retardation by S. Ali Mirhosseini, Lewis B. Holmes, and David S. Walton, June 1972, vol. 9, pp. 193-196.

An additional disorder, similar in some respects to the patients discussed, of nerve deafness, eye anomalies, and Marfanoid habitus has been described (Walker, 1971).

\section{REFERENCE}

Walker, A. B. (1971). A syndrome of nerve deafness, eye anomalies and Marfanoid habitus with autosomal dominant inheritance. In Birth Defects: Original Article Series, VIII, 4, pp. 137-139. National Foundation-March of Dimes, New York. 